\title{
Impacts of land use on an insectivorous tropical bat: the importance of mercury, physio-immunology and trophic position
}

\author{
David Costantini ${ }^{\mathrm{a}, \mathrm{b}, c *}$, Gábor Á. Czirják ${ }^{\mathrm{d}}$, Paco Bustamante ${ }^{\mathrm{e}}$, \\ Sara Bumrungsrif ${ }^{\mathrm{f}}$, Christian C. Voigt ${ }^{\mathrm{c}, \mathrm{g}}$
}

a UMR 7221 CNRS/MNHN, Muséum National d'Histoire Naturelle, Sorbonne Universités, 7 rue Cuvier, Paris 75005, France

b Department of Biology, University of Antwerp, Universiteitsplein 1, Antwerp 2610, Belgium

c Department of Evolutionary Ecology, Leibniz Institute for Zoo and Wildlife Research, Alfred-Kowalke-Straße 17, 10315 Berlin, Germany

${ }^{\mathrm{d}}$ Department of Wildlife Diseases, Leibniz Institute for Zoo and Wildlife Research, AlfredKowalke-Straße 17, 10315 Berlin, Germany

e Littoral Environnement et Sociétés, UMR 7266 CNRS-Université La Rochelle, 2 rue Olympe de Gouges, 17000 La Rochelle, France

${ }^{\mathrm{f}}$ Department of Biology, Faculty of Science, Prince of Songkla University, Hat Yai, Songkhla, Thailand

${ }^{\mathrm{g}}$ Institute of Biology, Freie Universität Berlin, Takustr. 6, Berlin 14195, Germany

* Corresponding author. Email address: david.costantini@mnhn.fr 


\section{ABSTRACT}

Deforestation, agricultural intensification, and habitat homogenization are critical threats to biodiversity in Southeast Asia. Limited information is available on the trophic and physiological responses of tropical animals to these environmental changes. The wrinklelipped free-tailed bat Chaerephon plicatus is a cave roosting species that is experiencing population declines across Southeast Asia, where landscapes have been drastically modified. In our study site in central Thailand, we tested the hypothesis that wrinkle-lipped free-tailed bats living in landscapes that contrast in heterogeneity and land-use differed in mercury contamination, trophic position and physio-immunological status. Bats from less heterogeneous landscapes (dominated by rice crops, absence of large forest patches) occupied a lower trophic position than conspecifics from more heterogeneous landscapes (including large forest patches). Additionally, bats from these habitats had lower concentrations of mercury in erythrocytes, lower body mass, higher antioxidant superoxide dismutase (SOD), lower antioxidant glutathione peroxidase (GPx) and lower values of the GPx/SOD ratio than bats from more heterogeneous landscapes. Individual bat mercury concentrations were positively correlated with body mass and two immune markers (lysozyme and immunoglobulin) but were negatively correlated with plasma non-enzymatic antioxidant capacity. Our results suggest various links between landscape heterogeneity, mercury accumulation/exposure, and health status of wildlife in Southeast Asian countries.

Keywords: Agriculture, Antioxidants, Deforestation, Oxidative stress, Rice, Stable isotopes, 


\section{Introduction}

Conversion of forests to agricultural areas has been a major way through which forests have vanished from tropical regions between 1990 and 2015 (FAO, 2015). The Food and Agriculture Organization estimate that South and Southeast Asia experienced the highest loss of canopy cover (over 50 million ha) from 2000 to 2012 and the highest loss in carbon stock from 2010 to 2015 compared to other regions (FAO, 2015). In many tropical regions, deforestation and conversion of natural lands into agricultural lands, soil erosion, and gold mining have also increased exposure of wildlife and humans to mercury contamination (Stubner et al., 1998; Horvat et al., 2003; Meng et al., 2010, 2011; Krisnayanti et al., 2012; Tang et al., 2018). For example, several studies in Asia have found that rice paddy soil hosts bacteria that can methylate inorganic mercury, which facilitates the bioaccumulation of mercury along food chains (e.g., Stubner et al., 1998; Meng et al. 2010, 2011). Mercury contamination is a priority topic for the United Nations (Minamata Convention) because it represents a significant threat to biodiversity, ecosystems, and human health (Eagles-Smith et al., 2018; Whitney and Cristol, 2018). Mercury is neurotoxic and can impair several functions in organisms, including reproduction and immunity (Whitney and Cristol, 2018).

Healthy ecosystems provide various services of economic value to humans. Bats are renowned for the services they provide to silviculture and agriculture (reviewed in Kunz et al., 2011; Ghanem and Voigt, 2012). For example, many bats are predators of pest insects in natural forests (Kalka et al., 2008; Böhm et al., 2011) and agricultural habitats (WilliamsGuillen et al., 2008; Maas et al., 2013). Bats may enhance crop production and economic benefits through a top-down reduction of herbivorous insects (Williams-Guillen et al., 2008; 
Boyles et al., 2011; Karp and Daily, 2014). However, bats are also one of the most threatened taxa (Voigt and Kingston, 2016; IUCN, 2018). While bat species diversity is higher in tropical regions, where land-use changes and mercury contamination are widespread, little work has been done to understand the effects of such environmental changes on tropical species as compared to other regions (Struebig et al., 2008, 2009; Syaripuddin et al., 2014; Becker et al., 2017, 2018a; Kumar et al., 2018). It is therefore important to identify potential threats for bats if we are to develop evidence-based landscape planning to limit anthropogenic impacts on bats and other wildlife.

In the last decade, there has been growing awareness that immunological and physiological techniques may allow conservation practitioners and wildlife managers to assess and, predict the impact of environmental changes on wildlife (Beaulieu and Costantini, 2014; Seltmann et al., 2017; Madliger et al., 2018; Becker et al., 2019). Immune markers are one important component of this toolbox because the immune system provides protection against parasites and pathogens (Martin et al., 2011). Oxidative status markers are also important because the generation of molecular oxidative damage and antioxidant defenses can affect important fitness-related traits (Beaulieu and Costantini, 2014). Both immunological and oxidative status markers provide complementary information about the impact of anthropogenic challenges on wildlife (Beaulieu and Costantini, 2014; Whitney and Cristol, 2018).

Changes in land-use also affect the amount and diversity of prey available for bats (Treitler et al., 2016). Measuring stable isotope ratios of nitrogen and carbon in tissues or body products (e.g., blood or fur, respectively) can provide information on what animals have 
consumed, in which habitat they foraged, and their trophic position (DeNiro and Epstein, 1978, 1981; Voigt and Kelm, 2006). This technique is based on the evidence that the isotope composition of an animal reflects that of its diet within a temporal window that depends on the isotopic incorporation rate of the analyzed tissue or body product (DeNiro and Epstein, 1978, 1981; Voigt and Kelm, 2006).

In this study, we tested the hypothesis that bats living in landscapes in Thailand that contrast in extension of forest patches and in the type of cultivated crops would differ in their trophic position, mercury contamination, and physio-immunological status. In particular, we used stable nitrogen and carbon isotope ratios in erythrocytes as a proxy for the trophic position and foraging behaviour of bats (Ruadreo et al., 2019). We measured mercury concentrations in erythrocytes because, conversely to other matrices (e.g., fur), they integrate mercury accumulated over the most immediate past, which is the reference period for the stable isotope ratios and physio-immunological parameters. Moreover, most mercury in blood is located in the erythrocytes (e.g., Kershaw et al., 1980; Magos, 1987; Berglund et al., 2005). We also measured the following physio-immunological parameters to assess bat health: body mass, four immunological markers, and four oxidative status markers. As study species, we selected the wrinkle-lipped free-tailed bat, Chaerephon plicatus (see supplementary material for a description of the species) because it forages above agricultural lands, it provides significant ecosystem services to the rice industry in Thailand and is experiencing population declines across Southeast Asia (Leelapaibul et al., 2005; Srilopan et al., 2018; Ruadreo et al. 2019). To this end, we selected four cave roosts that were located in landscapes with different land-use intensity within a radius of $25 \mathrm{~km}$ (assumed foraging area 
of the study species, Utthammachai, 2009; Wanger et al. 2014): more heterogeneous landscapes (mosaic of land uses, including large forest patches) and less heterogenous landscapes (dominated by farmlands, particularly rice crops, with only a few forest patches). We predicted that bats living in the less heterogenous landscapes would have a different trophic niche, higher erythrocyte concentrations of mercury, lower body mass, lower immune function, higher oxidative damage, and contrasting antioxidant defenses. We also predicted that bats with higher mercury concentrations would show lower immune function and higher oxidative stress.

\section{Material and Methods}

\subsection{Study area and sampling}

Sampling was carried out at four caves located in two habitat types (Table 1 and Fig. 1) during the non-reproductive season (end of July) to avoid disturbing breeding animals. We collected blood samples from 104 individuals: 15 males and 33 females from two caves located in more heterogeneous landscapes; 22 males and 34 females from two caves located in less heterogeneous landscapes dominated by rice crops. The fieldwork complied with the current laws of Thailand and were performed as part of permit \#0002/4508 granted by the National Research Council of Thailand (NRCT) and permit \#108/59 granted by the Department of National Park, Wildlife and Plant Conservation (DNP).

Upon capture (Table 1), bats were placed in individual holding bags. A blood sample was collected from the antebrachial vein using heparinised microvettes (Sarstedt, Nümbrecht, Germany) as outlined in Weise et al. (2017) within 30 minutes from capture (the order of 
bleeding was not significantly correlated with any physiological or immunological trait). Bats were released as soon as possible after bleeding. Blood samples were maintained cool until the end of the trapping session. Tubes were spun for five minutes, plasma was separated from the erythrocytes, and both were stored on dry ice while in the field and at $-80^{\circ} \mathrm{C}$ at the laboratory. From each bat, we identified sex and recorded body mass using a handheld spring balance (Pesola, Switzerland). All individuals were identified as adults because they were at least one year old according to the closure of the epiphyseal gap.

\subsection{Laboratory analyses}

\subsubsection{Stable carbon isotope and nitrogen isotopes}

Details regarding sample preparation and analysis are given in Ruadreo et al. (2019). Briefly, we measured stable carbon isotope ratios in dried samples using an elemental analyzer (Flash EA 1112, Thermo Scientific, Bremen, Germany) connected in sequence via a ConFlo to a Delta V Advantage isotope ratio mass spectrometer (both ThermoScientific, Bremen Germany). Values are reported in $\delta^{13} \mathrm{C}$ and $\delta^{15} \mathrm{~N}$ notation as parts per mille (\%o) deviation from the international standard V-PDB for carbon and atmospheric nitrogen for nitrogen. For both elements, analytical precision was always better than $0.1 \%$ (one standard deviation) for repeated measurements of laboratory protein standards.

\subsubsection{Mercury}

The total concentration of mercury was quantified in freeze-dried erythrocytes using an atomic absorption spectrophotometer (Advanced Mercury Analyser-254, Altec) on dried 
tissue aliquots (ranging from 0.5 to $3 \mathrm{mg}$ ) as described by Chouvelon et al. (2009). Prior work on bats has shown that the total concentration of mercury in blood is highly and positively correlated with the highly toxic methylated form (Yates et al., 2014). Total mercury in erythrocytes is also a proxy measure of methylmercury in humans (e.g., Skerfving, 1988; Sakamoto et al., 2002). The analytical quality (i.e., accuracy and reproducibility) of the mercury measurements was assessed by the analyses of blanks and certified reference material (CRM) TORT-2 Lobster Hepatopancreas (NRC, Canada; certified mercury concentration: $0.27 \pm 0.06 \mu \mathrm{g} / \mathrm{g} \mathrm{dw}$ ). The CRM were analyzed at the beginning and at the end of the analytical cycle, and by running controls for every 10 samples (Bustamante et al., 2008). Mass of the CRM was adjusted to represent an amount of mercury similar to that in bat samples. Our measured values for the CRM were $0.262 \pm 0.013 \mu \mathrm{g} / \mathrm{g}$ $\mathrm{dw}(\mathrm{n}=12)$ showing a recovery of $97 \%$. Blanks were analyzed at the beginning of each set of samples and the quantification limit of the method was $0.05 \mathrm{ng}$. Data for mercury concentrations are presented as $\mathrm{ng} / \mathrm{g}$ relative to the dry weight $(\mathrm{dw})$.

\subsubsection{Immunological markers}

We selected four immune markers used in eco-immunological studies (Demas et al., 2011), characterizing both constitutive (bacterial killing ability [BKA], lysozyme) and induced innate (haptoglobin) and adaptive (immunoglobulin $\mathrm{G}$ [IgG]) humoral immune responses (Heinrich et al., 2017). All these assays require small blood volumes and have been validated for bats (Schneeberger et al., 2013a, 2014a; Becker et al., 2017, 2018a; Ruoss et al., 2019). We report a detailed description of assays in the supplementary material. 


\subsubsection{Markers of oxidative status}

We selected four markers used in ecological studies of mammalian species (e.g., Costantini et al., 2012, 2017; Schneeberger et al., 2013b, 2014b) characterizing biomolecules that have been oxidized by free radicals (reactive oxygen metabolites), antioxidant protection from non-enzymatic antioxidants (e.g., those derived from diet), detoxification of cells from accumulation of hydrogen peroxide and organic hydroperoxides (activity of the enzyme glutathione peroxidase), and protection against the strong pro-oxidant action of the free radical superoxide generated by cells (activity of superoxide dismutase). We report a detailed description of assays in the supplementary material.

\subsection{Statistical analyses}

We used general linear models to compare isotopic signature, mercury, body mass, immunological markers and oxidative status markers between bats from more and less heterogeneous environments. We also compared the GPx/SOD ratio, because prior work found that unbalanced activities of the two enzymes may reflect an impaired physiological state (Park et al., 2007; Jayawardena et al., 2017). As fixed factors, we included landscape type (more vs. less heterogeneous landscape), individual sex, and their interaction. When individuals showed high values of Cook's distance (possible outliers; Cook, 1977) compared to the distribution of all Cook's distance values, they were excluded and the models were rerun to test whether their values were influential. Because time at which blood samples were taken varied among sites, we also ran unpaired t-tests to compare bats from the two caves (one in the more heterogeneous landscape and one in the less heterogeneous landscape) 
sampled at the same time of the day. We performed all analyses using SPSS Statistics 23. Finally, we used the compute.es package (Del Re, 2013) in R (R Core Team, 2013) to calculate the standardized effect size Hedges' g from test statistics. We used the forestplots function of the metafor package in R (Viechtbauer, 2010) to visualise values of effect size and $95 \%$ confidence interval. We considered the effect size estimates as small (Hedges $\mathrm{g}=$ 0.2 , explaining $1 \%$ of the variance), intermediate ( $\mathrm{g}=0.5$, explaining $9 \%$ of the variance) or large ( $g=0.8$, explaining $25 \%$ of the variance) according to Cohen (1988).

\section{Results}

Bats from the more heterogeneous landscapes had higher $\delta^{13} \mathrm{C}$ and $\delta^{15} \mathrm{~N}$ in erythrocytes than conspecifics from the less heterogeneous landscapes $(\mathrm{P}<0.001$, Supplementary Table $\mathrm{S} 1$, Fig. 2). Effect size estimates were large, and the $95 \%$ confidence intervals did not include zero for stable isotopes of both elements (Fig. 3). The significant interaction between environment and sex $\left(\mathrm{P}=0.001\right.$ for $\delta^{13} \mathrm{C}, \mathrm{P}=0.002$ for $\delta^{15} \mathrm{~N}$, Supplementary Table S1) indicated that sex differences in stable isotope ratios differed between environments. In the less heterogeneous landscapes, males and females had similar $\delta^{13} \mathrm{C}$ and $\delta^{15} \mathrm{~N}$ values (posthoc test: $\mathrm{P}=0.518$ for $\delta^{13} \mathrm{C}, \mathrm{P}=0.899$ for $\left.\delta^{15} \mathrm{~N}\right)$, whereas in the more heterogeneous landscapes males had higher $\delta^{13} \mathrm{C}(\mathrm{P}<0.001)$ and $\delta^{15} \mathrm{~N}$ values $(\mathrm{P}<0.001)$ than females.

Mercury concentrations in erythrocytes ranged from 16 to $602 \mathrm{ng} / \mathrm{g}$ dry weight and were similar in both sexes $(\mathrm{P}=0.13$, Supplementary Table $\mathrm{S} 1)$, but were higher in bats from more heterogeneous landscapes compared to conspecifics from less heterogeneous landscapes (P < 0.001, Supplementary Table S1, Fig. 4). Results for mercury did not vary 
when a female $(602 \mathrm{ng} / \mathrm{g})$ from Lan Sak Dristrict cave was removed because of its high Cook's distance. Effect size was large, and the $95 \%$ confidence interval did not include zero (Fig. 3).

Both male and female bats living in the less heterogeneous landscapes had lower body mass $(P=0.023$, Supplementary Table S1), higher SOD $(P=0.042$, Supplementary Table S1), lower GPx $(P=0.048$, Supplementary Table $S 1)$, and lower GPx/SOD ratios $(P=0.011$, Supplementary Table S1) than bats from more heterogeneous landscapes. All other markers were similar between bats living in the two environments (all $\mathrm{P}>0.250$, Supplementary Table S1). Outcomes for lysozyme concentrations were unchanged when a male $(6.29 \mu \mathrm{g} / \mathrm{ml})$ from Wat Khao Wongkot cave and a female $(9.46 \mu \mathrm{g} / \mathrm{ml})$ from Panurangsi with high Cook's distances were removed from the analyses. Males had higher OXY $(\mathrm{P}<0.001$, Supplementary Table S1) and plasma haptoglobin ( $\mathrm{P}=0.020$, Supplementary Table S1) than females irrespective of landscape. The difference in haptoglobin between sexes disappeared when a male $(1.42 \mathrm{mg} / \mathrm{ml})$ from Tha Luang District cave, and two males (2.05 and 3.19 $\mathrm{mg} / \mathrm{ml})$ and a female $(1.22 \mathrm{mg} / \mathrm{ml})$ from Wat Khao Wongkot cave with high Cook's distances were excluded from the model $(\mathrm{P}=0.128$, Supplementary Table $\mathrm{S} 1)$.

The comparison of bats from the two caves (Lan Sak Dristrict and Wat Khao Wongkot) that were sampled at a similar time of the day provided similar results to those from the whole dataset (Table 2). Bats living in the less heterogeneous landscape (Wat Khao Wongkot) had lower body mass $(\mathrm{P}=0.0003$, Table 2; Fig. 4), higher SOD $(\mathrm{P}=0.008$, Table 2, Fig. 5), lower GPx (P=0.014, Table 2, Fig. 5), and lower GPx/SOD ratios $(\mathrm{P}=0.001$, Table 2, Fig. 5) than bats from the more heterogeneous landscape, while all other markers 
were similar. The effect sizes for the significant differences were large, and the $95 \%$ confidence intervals did not overlap zero (Fig. 3). Although the effect sizes for lysozyme, haptoglobin, and BKA overlapped zero, they were intermediate and similar in sign, suggesting a potentially consistent effect of land-use on immune markers. This is more evident for the lysozyme, whose 95\% confidence interval for Hedges $g$ slightly included zero (Fig. 3).

There were small but significant negative correlations between mercury concentrations and either OXY or SOD and a significant positive correlation between mercury concentration and IgG (Supplementary Table S2). The correlation between mercury and SOD became non-significant when the individual with the highest mercury concentration (602 ng/g) was excluded (from $\mathrm{P}=0.042$ to $\mathrm{P}=0.236$, Supplementary Table S2). The positive correlation between mercury and lysozyme became significant after the exclusion of potential outliers (from $\mathrm{P}=0.488$ to $\mathrm{P}=0.043$, Supplementary Table S2). Larger bats had higher mercury concentrations in erythrocytes $(\mathrm{P}<0.001$, Supplementary Table S2). Relationships between mercury and markers were consistent across both landscapes (the interaction between environment and mercury was not significant).

\section{Discussion}

Our work shows that the mercury contamination, foraging ecology, and immunephysiological status of a tropical bat species may vary with habitat and sex. As expected, $\delta^{13} \mathrm{C}$ values of erythrocytes reflected the origin of the primary food sources in $\mathrm{C} 3$ - and $\mathrm{C} 4-$ dominated landscapes. Bats living in the less heterogeneous landscapes dominated by 
farmlands had lower $\delta^{13} \mathrm{C}$ values, indicating that the majority of consumed food sources originated from aquatic food webs such as rice paddies (Ruadreo et al., 2019). Food webs dominated by $\mathrm{C} 4$ plants, such as corn and cane sugar (higher $\delta^{13} \mathrm{C}$ values; De Niro and Epstein, 1978) did not largely contribute to bat diets in less heterogeneous landscapes. The less heterogeneous landscapes were dominated by rice crops (approximately $70 \%$ of rice crops in Wat Khao Wongkot; Srilopan et al., 2018; Ruadreo et al., 2019), which are planted during the non-reproductive season of Chaerephon plicatus (Ruadreo et al., 2019). In the less heterogeneous landscapes, bats also had lower $\delta^{15} \mathrm{~N}$, indicating that they occupy a lower trophic position (De Niro and Epstein, 1981). Prior work showed that wrinkle-lipped freetailed bats feed mainly on brown planthoppers and dipteran insects above rice fields of Central Thailand across the whole year (Srilopan et al., 2018; Ruadreo et al., 2019). In the less heterogeneous landscapes, males and females had similar isotopic composition in erythrocytes, which is in agreement with prior work on isotopic composition measured in both fur and wing tissue of bats living in the Wat Khao Wongkot bat-cave (Ruadreo et al., 2019). In the more heterogeneous environments, the isotopic composition in erythrocytes suggested a difference between males and females in trophic position and foraging areas. This might indicate that landscape homogenization could increase trophic overlap between males and females, possibly increasing food competition. Tracking the flight activity of bats would help to elucidate the foraging areas used by males and females.

Converse to our predictions, mercury was lower in bats living in the less heterogeneous landscapes. In Asia, soils of rice paddies may be sinks for mercury deposition and accumulation and provide an ideal environment for bacteria that methylate inorganic 
mercury (Stubner et al., 1998; Horvat et al., 2003; Meng et al., 2010, 2011; Feng et al., 2016; Tang et al., 2018). One reason for the lower concentration of mercury in bats from the less heterogeneous landscapes might relate to their lower trophic position as compared to bats from the more heterogeneous landscapes, which would be consistent with the hypothesis of a lower bioamplification effect due to shorter and less complex food webs. Mercury bioaccumulates with increasing trophic level due to the biomagnification process (EaglesSmith et al., 2018). Several studies show that insectivorous bats can accumulate significant amounts of mercury because of this biomagnification effect, particularly in species connected to aquatic ecosystems (Syaripuddin et al., 2014; Becker et al., 2018b). However, trophic position does not explain why males and females from the more heterogeneous environments had similar mercury concentrations despite their different trophic position. Further work will be needed to elucidate the causes of individual bat variation in mercury exposure.

The positive correlation between body mass and mercury also suggests that larger bats were probably accumulating more mercury through their diet, as previously shown for little brown bats Myotis lucifugus (Karouna-Renier et al., 2014). However, Kumar et al. (2018) found that smaller insectivorous bat species accumulated more mercury in fur than larger insectivorous species. In our current study, larger bats were from the more heterogeneous sites. Thus, the positive correlation between body mass and mercury may be caused by the dietary difference between sites. Further work will be needed to assess the diet of Chaerephon plicatus across different land-use regimes.

Although we do not know the extent to which mercury in erythrocytes reflected that accumulated in other tissues, prior work on bats found a strong and positive correlation 
between mercury in whole blood and fur (Wada et al., 2010; Karouna-Renier et al., 2014; Yates et al., 2014), indicating that blood concentration may provide a valuable proxy for the chronic accumulation of mercury. Assuming a water content of about $80 \%$ in whole blood (Eagles-Smith et al., 2008), values of mercury in bats living in the more heterogeneous landscapes would be equivalent to an average of $42.6 \mathrm{ng} / \mathrm{g}$ wet weight and a range from 3.2 to $120 \mathrm{ng} / \mathrm{g}$ wet weight. Although the average value is similar to that found in other bat species living far from potential sources for contamination (Yates et al., 2014), values are within the range recorded in bats living near contamination sources (Wada et al., 2010; Karouna-Renier et al., 2014; Yates et al., 2014). For example, big brown bats Eptesicus fuscus from a contaminated site in the USA showed a range of mercury in blood from 50 to $200 \mathrm{ng} / \mathrm{g}$ wet weight (Wada et al., 2010). In little brown bats from three contaminated sites in the USA, mercury in blood ranged from 14 to 3,800 ng/g wet weight (Karouna-Renier et al., 2014). We are not aware of any specific sources of mercury emission near caves located in the more heterogeneous landscapes. One tentative explanation might lie with the filtering properties of forest canopy that would favor accumulation of mercury in wetlands through flooding, soil erosion, and decomposition of organic matter (Barbosa et al., 2003; Driscoll et al., 2007). In Uthai Thani, where one of the caves was located, deforestation and conversion of residual forest lands into agricultural lands is a major problem (Waiyasusri et al., 2016). Moreover, both the cave in Uthai Thani and that in the Tha Luang District (i.e., those located in the more heterogeneous landscapes) were close (within a radius of $25 \mathrm{~km}$ from the cave) to two large watersheds (Huai Thap Salao Dam and Pa Sak Dam, respectively) that might work as sinks for mercury washed away from soil. Analyses of mercury concentration in the 
environment and prey will be important to ascertain the routes through which wrinkle-lipped free-tailed bats are being exposed to mercury.

Mercury is neurotoxic and can also cause many other potentially negative effects on traits like behaviour, endocrine system, immune function and cellular oxidative status and thus likely reproduction and survival (Tan et al., 2009; Whitney and Cristol, 2018). Bats with a higher concentration of mercury in erythrocytes had lower OXY in plasma and SOD in erythrocytes. This lower antioxidant protection might indicate that bats were exposed to higher cellular oxidative stress. However, we did not find any correlation between mercury and reactive oxygen metabolites. Whether mercury may increase cellular oxidative damages in wrinkle-lipped free-tailed bats remains an open question.

Our analyses also showed that bats with higher blood mercury had higher IgG and lysozyme concentrations when outliers were removed. The reasons for these correlations are currently unclear. Mercury may affect different aspects of immune function (Becker et al., 2017; Whitney and Cristol, 2018). Higher concentrations of IgG and lysozyme in bats with more blood mercury may also reflect higher parasite loads that stimulate the constitutive innate and adaptive immune responses. We observed many ectoparasites on bats in these sites (unpublished data), which might have stimulated constitutive innate and adaptive immune responses.

None of the immune markers differed largely between bats from the less or more heterogeneous landscapes. The effect size estimates for lysozyme, haptoglobin, and BKA were similar, intermediate in size, and indicated higher values in the less heterogeneous landscapes. Although the $95 \%$ confidence intervals for the effect size estimates of the three 
immune markers included zero, these estimates were similar in sign and size. This result stimulates further work with a larger sample size that also considers careful estimates of parasite burdens to clarify whether land-use affects immune function independently from mercury exposure. Presently, our data here suggest that some aspects of anthropogenic land use might have a stronger connection with oxidative status markers. Bats in the less heterogeneous landscapes had higher SOD and lower GPX, resulting in significant lower GPx/SOD ratios. However, conversely to our prediction, plasma reactive oxygen metabolites (marker of early derivatives of oxidative damage) did not differ between bats in the two environments.

We currently do not know the reasons for such differences in GPx and SOD and if they have any functional consequences. We might exclude a strong role of mercury contamination because the correlation with SOD was small and it was not associated with GPx nor with GPx/SOD ratio. Thus, other factors such as foraging effort, diet quality, and pesticide exposure might be involved.

\section{Conclusions}

In conclusion, our study showed that land-use was associated with foraging ecology, mercury contamination, and oxidative status in a tropical insectivorous bat species. Further, our study also showed that mercury concentrations were correlated with individual body mass and immune function. We conclude that a combination of several endogenous markers can generate a more comprehensive picture about how land-use changes may affect wildlife. 
Further work will be needed to ascertain the ecological relevance of the mercury concentrations we detected in bats.

Finally, our study suggests a possibly useful application to landscape planning that might inform stakeholders and policy makers on how to develop plans for land-use in a more compatible way with bats' ecological needs. As expected, our results suggested that environments with intensive agricultural practices might be less suitable for insectivorous bats than more heterogeneous environments. However, our data also showed that bottom-up effects of landscape composition may come through unexpected routes, such as mercury exposure. For example, deforestation near watersheds or other wetlands might increase mercury exposure as suggested by results from bats living in the province of Uthai Thani. This would call for a strict protection of forest patches in order to avoid soil erosion and washing out of mercury into watersheds.

\section{Acknowledgements}

This work was supported by the Alexander-von-Humboldt-Foundation and funds from Leibniz Institute for Zoo and Wildlife Research. We are grateful to the platform "Analyses Elémentaires" of LIENSs for the access to their analytical facilities. We are also grateful to the CPER (Contrat de Projet État-Région) and the FEDER (European Regional Development Fund) for funding the AMA. The IUF (Institut Universitaire de France) is also acknowledged for its support to PB as a Senior Member. The authors wish to thank Katja Pohle and Yvonne Klaar for technical assistance in the lab, students for assistance in fieldwork, Daniel J. Becker 
for kindly correcting our English, the editor and two reviewers for providing valuable and constructive comments on our manuscript.

\section{Data Availability}

The datasets analyzed during the current study are available from the corresponding author on reasonable request.

\section{References}

Barbosa, A.C., de Souza, J., Dórea, J.G., Jardim, W.F., Fadini, P.S., 2003. Mercury biomagnification in a tropical black water, Rio Negro, Brazil. Arch. Environ. Contam. Toxicol. 45, 235-246.

Beaulieu, M., Costantini, D., 2014. Biomarkers of oxidative status: missing tools in conservation physiology. Conserv. Physiol. 2, cou014.

Becker, D.J., Chumchal, M.M., Bentz, A.B., Platt, S.G., Czirják, G.Á., Rainwater, T.R., Altizer, S., Streicker, D.G., 2017. Predictors and immunological correlates of sublethal mercury exposure in vampire bats. R. Soc. Open Sci. 4, 170073.

Becker, D.J., Czirják, G.Á., Volokhov, D.V., Bentz, A.B., Carrera, J.E., Camus, M.S., Navara, K.J., Chizhikov, V.E., Simmons, N.B., Fenton, M.B., Recuenco, S.E., Gilbert, A.T., Altizer, S., Streicker, D.G., 2018a. Livestock abundance predicts vampire bat demography, immune profiles, and bacterial infection risk. Phil. Trans. R. Soc. B 373, 20170089.

Becker, D.J., Chumchal, M.M., Broders, H.G., Korstian, J.M., Clare, E.L., Rainwater, T.R., Platt, S.G., Simmons, N.B., Fenton, M.B., 2018b. Mercury bioaccumulation in bats reflects dietary connectivity to aquatic food webs. Environ. Pollut. 233, 1076-1085.

Becker, D.J., Nachtmann, C., Argibay, H.D., Botto, G., Escalera-Zamudio, M., Carrera, J.E., Tello, C., Winiarski, E., Greenwood, A.D., Méndez-Ojeda, M.L., Loza-Rubio, E., Lavergne, A., de Thoisy, B., Czirják, G.Á., Plowright, R.K., Altizer, S., Streicker, D.G., 
2019. Leukocyte profiles reflect geographic range limits in a widespread Neotropical bat. Integr. Comp. Biol., in press.

Berglund, M., Lind, B., Björnberg, K.A., Palm, B., Einarsson, O., Vahter, M., 2005. Interindividual variations of human mercury exposure biomarkers: a cross-sectional assessment. Environ. Health. 4, 20.

Böhm, S.M., Wells, K., Kalko, E.K.V., 2011. Top-down control of herbivory by birds and bats in the canopy of temperate broad-leaved oaks (Quercus robur). PLoS One 6, e17857.

Boyles, J.G., Cryan, P.M., McCracken, G.F., Kunz, T.H., 2011. Economic importance of bats in agriculture. Science 332, 41-42.

Bustamante, P., Gonzàlez, A.F., Rocha, F., Miramand, P., Guerra, A., 2008. Metal and metalloid concentrations in the giant squid Architeuthis dux from Iberian waters. Mar. Environ. Res. 66, 278-287.

Chouvelon, T., Warnau, M., Churlaud, C., Bustamante, P., 2009. Hg concentrations and related risk assessment in coral reef crustaceans, molluscs and fish from New Caledonia. Environ. Pollut. 157, 331-340.

Cohen, J., 1988. Power analysis for the behavioural sciences. Erlbaum, Hillsdale.

Cook, R.D., 1977. Detection of influential observation in linear regression. Technometrics $19,15-18$.

Costantini, D., Ferrari, C., Pasquaretta, C., Cavallone, E., Carere, C., von Hardenberg, A., Réale, D., 2012. Interplay between plasma oxidative status, cortisol and coping styles in wild alpine marmots, Marmota marmota. J. Exp. Biol. 215, 374-383.

Costantini, D., Wachter, B., Melzheimer, J., Czirják, G.Á., 2017. Socioecological and environmental predictors of physiological stress markers in a threatened feline species. Conserv. Physiol. 5, cox069.

Del Re, A.C., 2013. Compute.es: compute effect sizes. R package version 0.2-2. Available from: http://cran.r-project.org/web/packages/compute.es.

Demas, G.E., Zysling, D.A., Beechler, B.R., Muehleiben, M.P., French, S.S., 2011. Beyond phytohaemagglutinin: assessing vertebrate immune function across ecological contexts. J. Anim. Ecol. 80, 710-730. 
Deniro, M.J., Epstein, S., 1981. Influence of diet on the distribution of nitrogen isotopes in animals. Geochim. Cosmochim. Acta 45, 341-351.

Deniro, M.J., Epstein, S., 1981. Influence of diet on the distribution of carbon isotopes in animals. Geochim. Cosmochim. Acta 42, 495-506.

Driscoll, C.T., Han, Y.J., Chen, C.Y., Evers, D.C., Lambert, K.F., Holsen, T.M., Kamman, N.C., Munson, R.K., 2007. Mercury contamination in forest and freshwater ecosystems in the Northeastern United States. BioScience 57, 17-28.

Eagles-Smith, C.A., Ackerman, J.T., Adelsbach, T.L., Takekawa, J.Y., Miles, A.K., Keister, R.A., 2008. Mercury correlations among six tissues for four waterbird species breeding in San Francisco Bay, California, USA. Environ. Toxicol. Chem. 27, 2136-2153.

Eagles-Smith, C.A., Silbergeld, E.K., Basu, N., Bustamante, P., Diaz-Barriga, F., Hopkins, W.A., Kidd, K.A., Nyland, J.F., 2018. Modulators of mercury risk to wildlife and humans in the context of rapid global change. Ambio 47, 170-197.

FAO, 2015. Global Forest Resources Assessment 2015: How have the world's forests changed? Rome, Italy.

Feng, C., Pedrero, Z., Li, P., Du, B., Feng, X., Monperrus, M., Tessier, E., Berail, S., Amouroux, D., 2016. Investigation of $\mathrm{Hg}$ uptake and transport between paddy soil and rice seeds combining $\mathrm{Hg}$ isotopic composition and speciation. Elem. Sci. Anth. 4, 87.

Ghanem, S.J., Voigt, C.C., 2012. Increasing awareness of ecosystem services provided by bats. Adv. Study Behav. 44, 279-302.

Halliwell, B.H., Gutteridge, J.M.C., 2007. Free radicals in biology and medicine. Oxford University Press, Oxford, UK.

Heinrich, S.K., Hofer, H., Courtiol, A., Melzheimer, J., Dehnhard, M., Czirják, G.Á., Wachter, B., 2017. Cheetahs have a stronger constitutive innate immunity than leopards. Sci. Rep. 7, 44837.

Horvat, M., Nolde, N., Fajon, V., Jereb, V., Logar, M., Lojen, S., Jacimovic, R., Falnoga, I., Liya, Q., Faganeli, J., Drobne D., 2003. Total mercury, methylmercury and selenium in mercury polluted areas in the province Guizhou, China. Sci. Total Environ. 304, 231-256. 
IUCN, 2018. The IUCN Red List of Threatened Species. Version 2018-1. http://www. iucnredlist.org.

Jayawardena, U.A., Angunawela, P., Wickramasinghe, D.D., Ratnasooriya, W.D., Udagama, P.V., 2017. Heavy metal-induced toxicity in the Indian green frog: biochemical and histopathological alterations. Environ. Toxicol. Chem. 36, 2855-2867.

Kalka, M.B., Smith, A.R., Kalko, E.K.V., 2008. Bats limit arthropods and herbivory in a tropical forest. Science 320, 71.

Karouna-Renier, N.K., White, C., Perkins, C.R., Schmerfeld, J.J., Yates, D., 2014. Assessment of mitochondrial DNA damage in little brown bats (Myotis lucifugus) collected near a mercury-contaminated river. Ecotoxicol. 23, 1419-1429.

Karp, D.S., Daily, G.C., 2014. Cascading effects of insectivorous birds and bats in tropical coffee plantations. Ecology 95, 1065-1074.

Kershaw, T.G., Clarkson, T.W., Dhahir, P.H., 1988. The relationship between blood levels and dose of methylmercury in man. Arch. Environ. Health. 35, 28-36.

Krisnayanti, B.D., Anderson, C.W.N., Utomo, W.H., Feng, X., Handayanto, E., Mudarisna, N., Ikram, H., Khususiah, 2012. Assessment of environmental mercury discharge at a four-year old artisanal gold mining area on Lombok Island, Indonesia. J. Environ. Monitor. 14, 2598-2607.

Kumar, A., Divoll, T.J., Ganguli, P.M., Trama, F.A., Lamborg, C.H., 2018. Presence of artisanal gold mining predicts mercury bioaccumulation in five genera of bats (Chiroptera). Environ. Pollut. 236, 862-870.

Kunz, T.H., Braun de Torrez, E., Bauer, D., Lobova, T., Fleming, T.H., 2011. Ecosystem services provided by bats. Ann. N. Y. Acad. Sci. 1223, 1-38.

Leelapaibul, W., Bumrungsri, S., Pattanawiboon, A., 2005. Diet of wrinkle-lipped free-tailed bat (Tadarida plicata Buchannan, 1800) in central Thailand: insectivorous bats potentially act as biological pest control agents. Acta Chiropterol. 7, 111-119.

Maas, B., Clough, Y., Tscharntke, T., 2013. Bats and birds increase crop yield in tropical agroforestry landscapes. Ecol. Lett. 16, 1480-1487. 
Madliger, C.L., Love, O.P., Hultine, K.R., Cooke, S.J., 2018. The conservation physiology toolbox: status and opportunities. Conserv. Physiol. 6, coy029.

Magos, L., 1987. The absorption, distribution and excretion of methyl mercury, in: Eccles, C.V., Annau, Z. (Eds.), The toxicity of methylmercury. Johns Hopkins University Press, Baltimore, pp. 24-44.

Martin, L.B., Hawley, D.M., Ardia, D.R., 2011. An introduction to ecological immunology. Funct. Ecol. 25, 1-4.

Meng, B., Feng, X., Qiu, G., Cai, Y., Wang, D., Li, P., Shang, L., Sommar, J., 2010. Distribution patterns of inorganic mercury and methylmercury in tissues of rice (Oryza sativa L.) plants and possible bioaccumulation pathways. J. Agric. Food Chem. 58, 49514958.

Meng, B., Feng, X., Qiu, G., Liang, P., Li, P., Chen, C., Shang, L., 2011. The process of methylmercury accumulation in rice (Oryza sativa L.). Environ. Sci. Technol. 45, 27112717.

Park, E.-M., Ramnath, N., Yang, G.Y., Ahn, J.-Y., Park, Y., Lee, T.-Y., Shin, H.-S., Yu, J., Ip, C., Park, Y.-M., 2007. High SOD and low GPX activities in RBC predict susceptibility of lung cancer patients to radiation pneumonitis. Free Radic. Biol. Medic. 42, 280-287.

R Core Team, et al., (2013) R: A language and environment for statistical computing. R Foundation for Statistical Computing Vienna, Austria. Available from: https://www.Rproject.org/.

Ruadreo, N., Voigt, C.C., Bumrungsri, S., 2019. Large dietary niche overlap of sympatric open-space foraging bats revealed by carbon and nitrogen stable isotopes. Acta Chiropterol. 20: 329-341.

Ruoss, S., Becker, N.I., Otto, M.S., Czirják, G.Á., Encarnação, J.A., 2019. Effect of sex and reproductive status on the immunity of the temperate bat Myotis daubentonii. Mammal Biol. 94: 120-126.

Sakamoto, M., Kubota, M., Matsumoto, S., Nakano, A., Akagi, H., 2002. Declining risk of methylmercury exposure to infants during lactation. Environ. Res. 90, 185-189. 
Schneeberger, K., Czirják, G.Á., Voigt, C.C., 2013a. Measures of the constitutive immune system are linked to diet and roosting habits of Neotropical bat species. PLoS ONE 8, e54023.

Schneeberger, K., Czirják, G.Á., Voigt, C.C., 2013b. Inflammatory challenge increases measures of oxidative stress in a free-ranging, long-lived mammal. J. Exp. Biol. 216, 4514-4519.

Schneeberger, K., Courtiol, A., Czirják, G.Á., Voigt, C.C., 2014a. Immune profile predicts survival in a small, long-lived bat, the greater sac-winged bat (Saccopteryx bilineata). PLoS ONE 9, e108268.

Schneeberger, K., Czirják, G.Á., Voigt, C.C., 2014b. Frugivory is associated with low measures of plasma oxidative stress and high antioxidant concentration in free-ranging bats. Naturwissenschaften 101, 285-290.

Seltmann, A., Czirják, G.Á., Struebig, M., Courtiol, A., Bernard, H., Voigt, C.C., 2017. Habitat disturbance results in chronic stress and impaired health status in forest-dwelling paleotropical bats. Conserv. Physiol. 5, cox020.

Srilopan, S., Bumrungsri, S., Jantarit, S., 2018. The wrinkle-lipped free-tailed bat (Chaerephon plicatus Buchannan, 1800) feeds mainly on brown planthoppers in rice fields of Central Thailand. Acta Chiropterol. 20, 207-219.

Skerfving, S., 1988. Mercury in women exposed to methylmercury through fish consumption, and in their newborn babies and breast milk. Bull. Environ. Contam. Toxicol. 41, 475-482.

Struebig, M.J., Kingston, T., Zubaid, A., Mohd-Adnan, A., Rossiter, S.J., 2008. Conservation value of forest fragments to Palaeotropical bats. Biol. Conserv. 141, 2112-2126.

Struebig, M.J., Kingston, T., Zubaid, A., Le Comber, S.C., Mohd-Adnan, A., Turner, A., Kelly, J., Bożek, M., Rossiter, S.J., 2009. Conservation importance of limestone karst outcrops for Palaeotropical bats in a fragmented landscape. Biol. Conserv. 142, 20892096. 
Stubner, S., Wind, T., Conrad, R., 1998. Sulfur oxidation in rice field soil: activity, enumeration, isolation and characterization of thiosulfate-oxidizing bacteria. Syst. Appl. Microbiol. 21, 569-578.

Syaripuddin, K., Kumar, A., Sing, K.-W., Halim, M.-R., Nursyereen, M.-N., Wilson, J.-J., 2014. Mercury accumulation in bats near hydroelectric reservoirs in Peninsular Malaysia. Ecotoxicol. 23, 1164-1171.

Tan, S.W., Meiller, J.C., Mahaffey, K.R., 2009. The endocrine effects of mercury in humans and wildlife. Critical Rev. Toxicol. 39, 228-269.

Tang, Z., Fan, F., Wang, X., Shi, X., Deng, S., Wang, D., 2018. Mercury in rice (Oryza sativa L.) and rice-paddy soils under long-term fertilizer and organic amendment. Ecotoxicol. Environ. Saf. 150, 116-122.

Treitler, J.T., Heim, O., Tschapka, M., Jung, K., 2016. The effect of local land use and loss of forests on bats and nocturnal insects. Ecol. Evol. 6, 4289-4297.

Utthammachai, K., 2009. Foraging habitat use by acoustic monitoring of Tadarida plicata (Buchannan, 1800) in an agricultural landscape, Ratchaburi province. Kasetsart University/Bangkok.

Viechtbauer, W., 2010. Conducting meta-analyses in R with the metafor package. J. Statist. Software 36, 1-48.

Voigt, C.C., Kelm, D.H., 2006. Host preference of the common vampire bat (Desmodus rotundus; Chiroptera) assessed by stable isotopes. J. Mammal. 87, 1-6.

Voigt, C.C., Kingston, T., 2016. Bats in the Anthropocene: conservation of bats in a changing world. Springer Science Business Media.

Wada, H., Yates, D.E., Evers, D.C., Taylor, R.J., Hopkins, W.A., 2010. Tissue mercury concentrations and adrenocortical responses of female big brown bats (Eptesicus fuscus) near a contaminated river. Ecotoxicol. 19, 1277-1284.

Waiyasusri, K., Yumuang, S., Chotpantarat, S., 2016. Monitoring and predicting land use changes in the Huai Thap Salao Watershed area, Uthaithani Province, Thailand, using the CLUE-s model. Environ. Earth Sci. 75, 533. 
Wanger, T.C., Darras, K., Bumrungsri, S., Tscharntke, T., Klein, A.-M., 2014. Bat pest control contributes to food security in Thailand. Biol. Conserv. 171, 220-223.

Weise, P., Czirják, G.Á., Lindecke, O., Bumrungsri, S., Voigt, C.C., 2017. Simulated bacterial infection disrupts the circadian fluctuation of immune cells in wrinkle-lipped bats (Chaerephon plicatus). PeerJ 5, e3570.

Whitney, M.C., Cristol, D.A., 2018. Impacts of sublethal mercury exposure on birds: a detailed review. Rev. Environ. Contam. Toxicol. 244, 113-163.

Williams-Guillen, K., Perfecto, I., Vandermeer, J., 2008. Bats limit insects in a neotropical agroforestry system. Science 320, 70.

Yates, D.E., Adams, E.M., Angelo, S.E., Evers, D.C., Schmerfeld, J., Moore, M.S., Kunz, T.H., Divoll, T., Edmonds, S.T., Perkins, C., Taylor, R., O’Driscoll, N.J., 2014. Mercury in bats from the northeastern United States. Ecotoxicol. 23, 45-55 


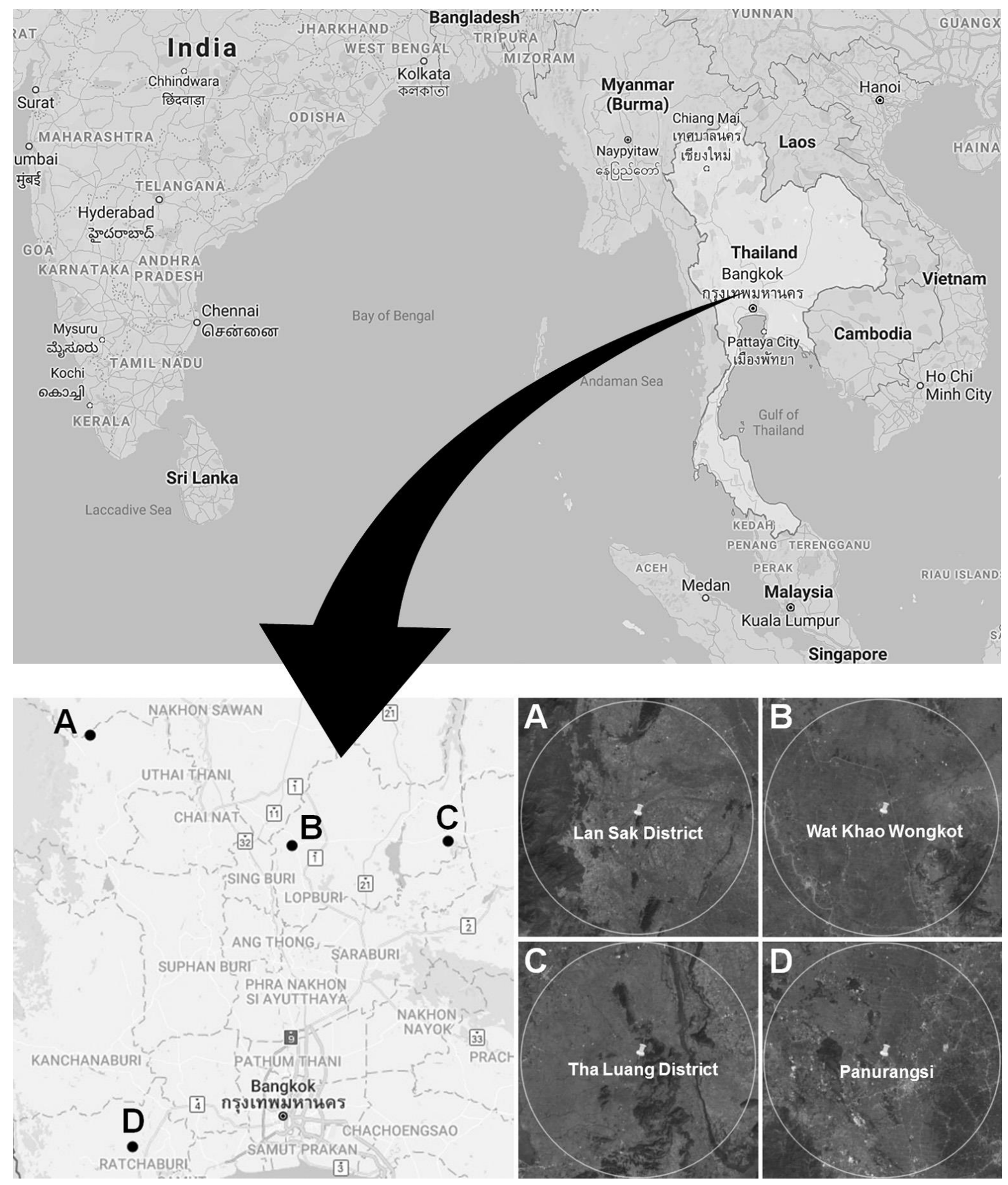

Figure 1. Map and aerial photographs illustrating the locations of caves in Thailand. Circles show a radius of $25 \mathrm{~km}$ from the cave, which indicates the distance within which bats can forage (Utthammachai, 2009; Wanger et al. 2014). Sources of images: Google Maps and Google Earth Pro, C2018 Google. 


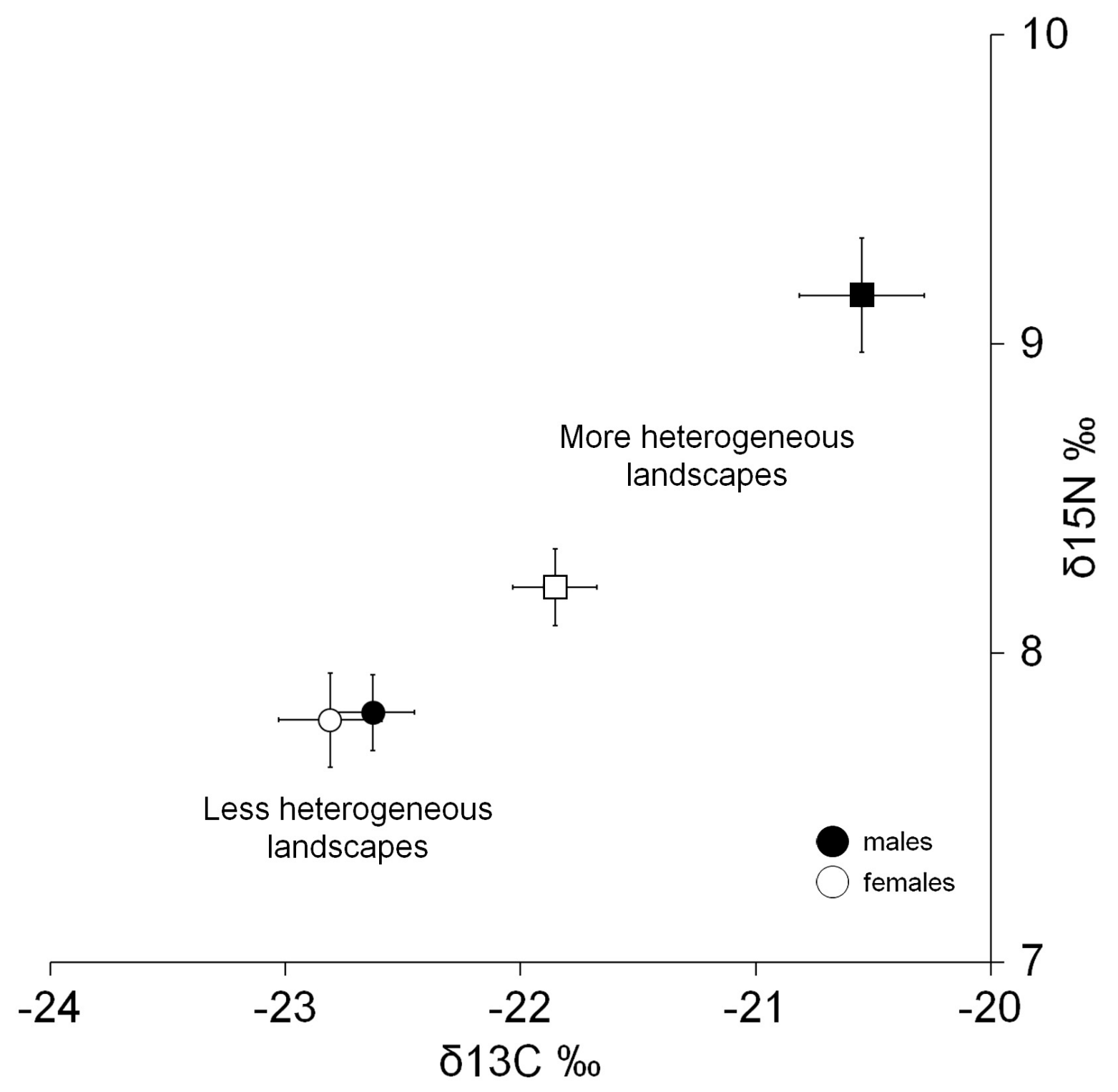

Figure 2. Bats living in landscapes dominated by farmlands (mostly rice crops) had lower carbon and nitrogen stable isotopes in erythrocytes than bats living in more heterogeneous environments. In agricultural landscapes, males and females had similar $\delta^{13} \mathrm{C}$ and $\delta^{15} \mathrm{~N}$, while in the more heterogeneous landscapes, males had higher $\delta^{13} \mathrm{C}$ than females. Values are shown as means and standard error. 


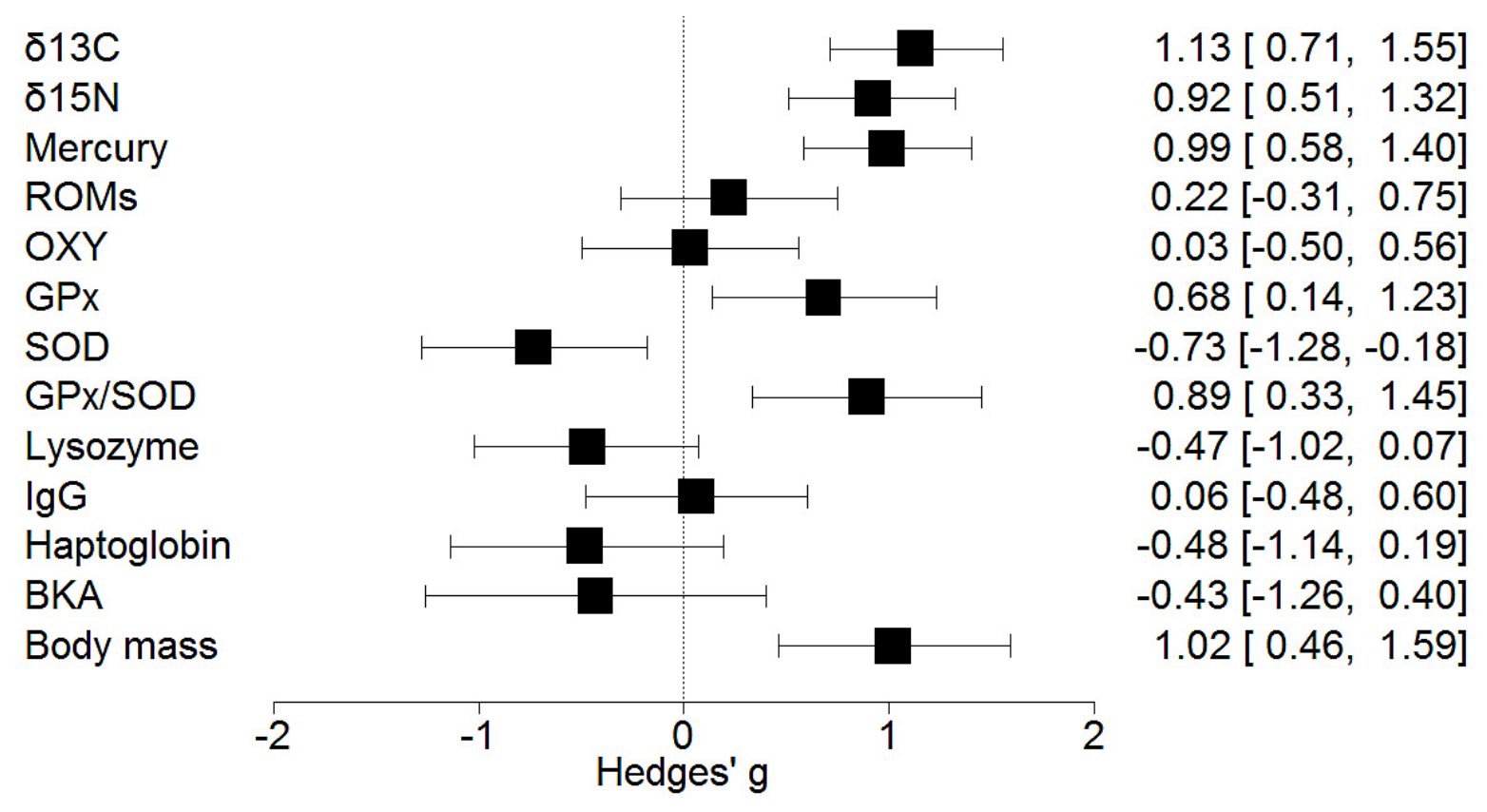

Figure 3. Estimates of effect size (Hedges' $g$ ) and 95\% confidence intervals from the two caves where samples were collected at a similar time of the day. Estimates are positive or negative when values of a given metric were higher or lower in bats from more heterogeneous landscapes, respectively. 

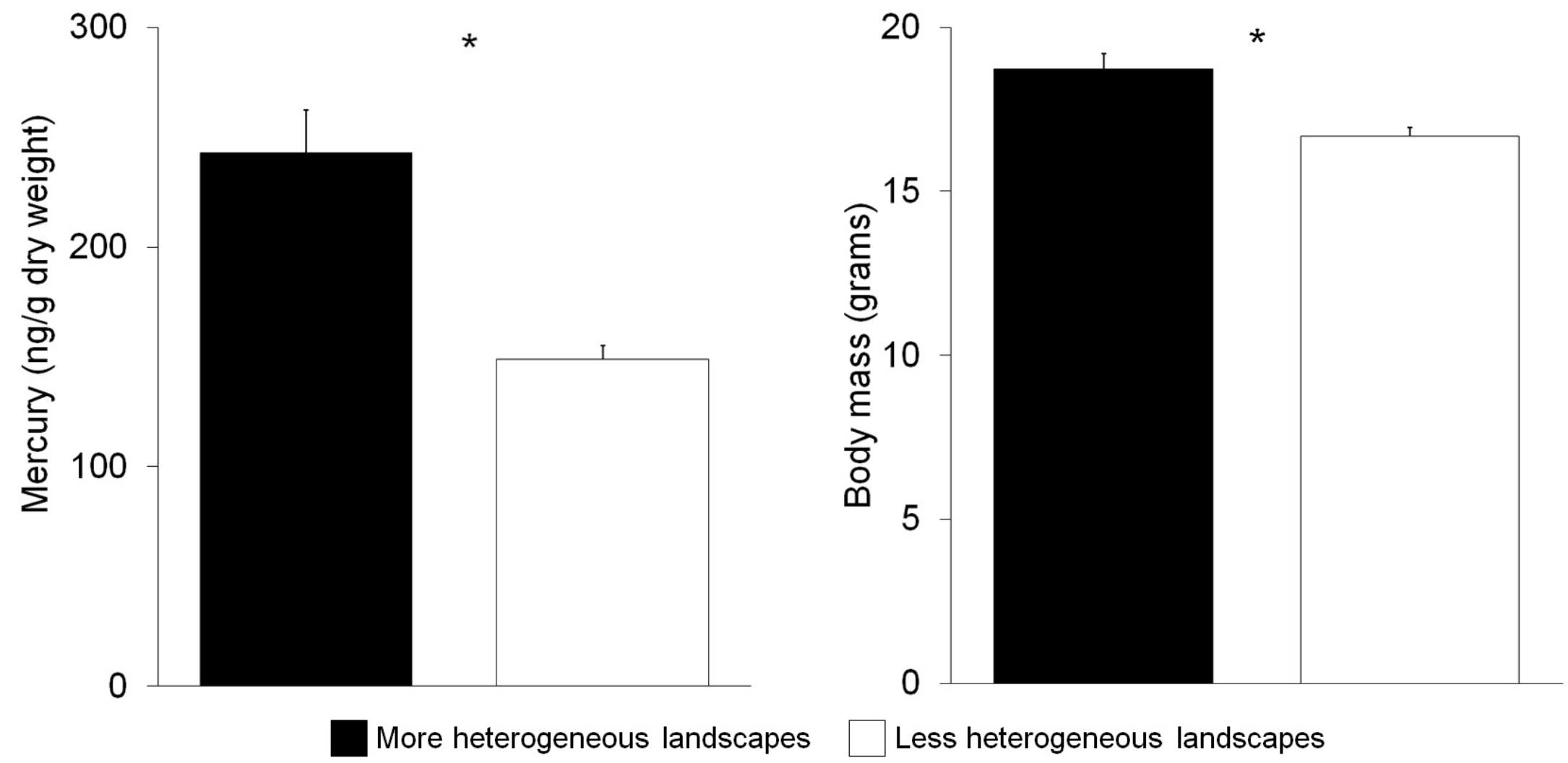

Figure 4. Means and standard errors for mercury concentration in erythrocytes and for body mass. * indicates a statistically significant difference. 

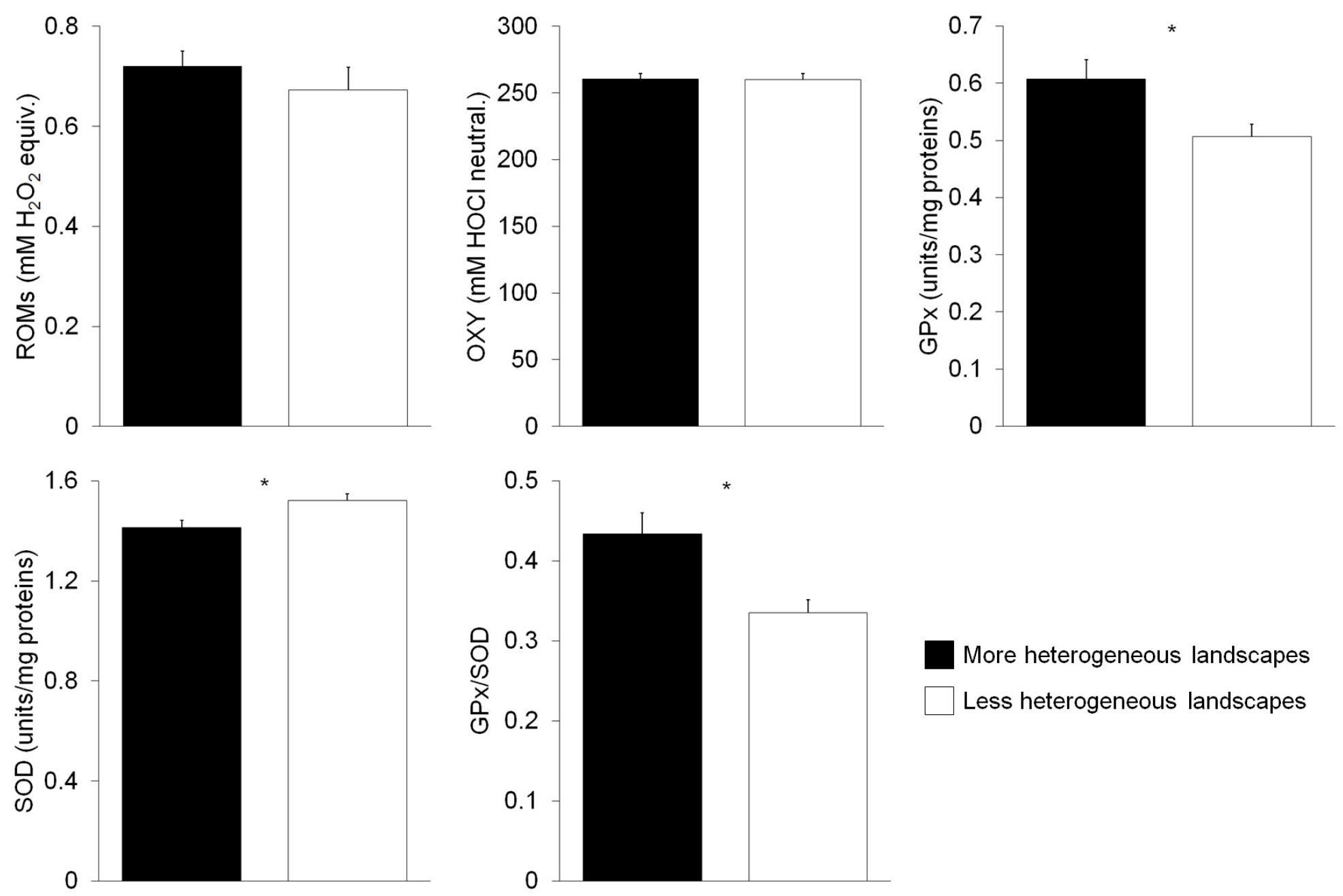

Figure 5. Means and standard errors for all markers of oxidative status analysed in the present study. ROMs $=$ reactive oxygen metabolites; OXY = plasma non-enzymatic antioxidant capacity; GPx = glutathione peroxidase; SOD = superoxide dismutase. $*$ indicates a statistically significant difference. 

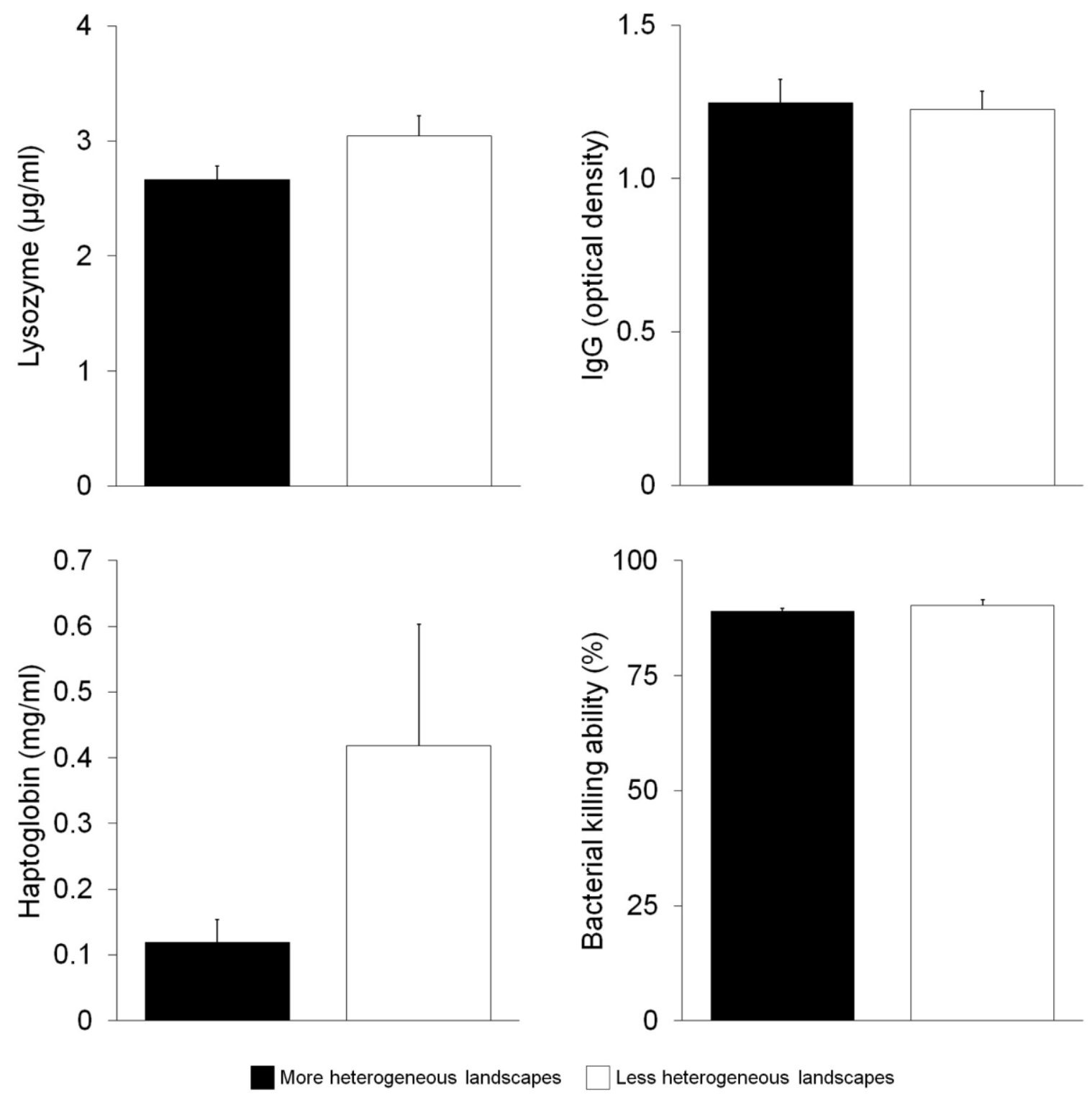

Figure 6. Means and standard errors for all immune markers analysed in the present study. $\mathrm{IgG}=$ immunoglobulin $\mathrm{G}$. 
Table 1. The fieldwork included four caves located in more or less heterogeneous landscapes. The more heterogeneous sites also included forest patches. The less heterogeneous sites did not include any forest patches and had a dominance of agricultural lands (mainly rice crops) according to data availability (Geo-Informatics and Space Technology Development Agency; Google Earth Pro; * Srilopan et al., 2018; see also Wanger et al., 2014). The distance among caves ranged from ca. 80 to $230 \mathrm{~km}$. All the provinces where caves were located had experienced significant changes in land cover.

\begin{tabular}{|c|c|c|c|}
\hline Site of the cave & Coordinates & Landscape & Method and time of capture \\
\hline $\begin{array}{l}\text { Tha Luang Dristict } \\
\text { (province Lop Buri) }\end{array}$ & $\begin{array}{l}15.0416710^{\circ} ; \\
101.3150630^{\circ}\end{array}$ & $\begin{array}{l}\text { Agricultural lands (corn } \\
\text { and sugar cane) and } \\
\text { large forest patches }\end{array}$ & $\begin{array}{l}\text { Mist-netting at dusk in front to } \\
\text { the cave }\end{array}$ \\
\hline $\begin{array}{l}\text { Wat Khao Wongkot bat- } \\
\text { cave (province Lop Buri) }\end{array}$ & $\begin{array}{l}15.01814459^{\circ} ; \\
100.54520403^{\circ}\end{array}$ & $\begin{array}{l}\text { Landscape dominated by } \\
\text { agricultural lands ( } \\
70 \% \text { rice crops } * \text {, less } \\
\text { than } 5 \% \text { of forest } \\
\text { patches) }\end{array}$ & $\begin{array}{l}\text { Butterfly net, early in the } \\
\text { morning into the cave }\end{array}$ \\
\hline $\begin{array}{l}\text { Wat Khao Pha Rad, Lan } \\
\text { Sak Dristrict (province } \\
\text { Uthai Thani) }\end{array}$ & $\begin{array}{l}15.5439650^{\circ} ; \\
99.5510480^{\circ}\end{array}$ & $\begin{array}{l}\text { Agricultural lands (corn } \\
\text { and sugar cane) and } \\
\text { large forest patches }\end{array}$ & $\begin{array}{l}\text { Butterfly net, early in the } \\
\text { morning into the cave }\end{array}$ \\
\hline $\begin{array}{l}\text { Panurangsi Golf Club } \\
\text { (province Ratchaburi) }\end{array}$ & $\begin{array}{l}13.5807760^{\circ} ; \\
99.7618250^{\circ}\end{array}$ & $\begin{array}{l}\text { Landscape dominated by } \\
\text { agricultural lands (rice } \\
\text { crops, oil palms; less } \\
\text { than } 5 \% \text { of forest } \\
\text { patches) }\end{array}$ & $\begin{array}{l}\text { Mist-netting at sunrise in front } \\
\text { to the cave }\end{array}$ \\
\hline
\end{tabular}


Table 2. Outcomes of unpaired t-tests performed to compare bats from Lan Sak Dristrict cave (reference cave, more heterogeneous landscape) with those from Wat Khao Wongkot cave (less heterogeneous landscape, approximately $70 \%$ of rice crops) because they were sampled at a similar time of the day. Significant effects are shown in bold type.

\begin{tabular}{lccl}
\hline Variable & t-value & $\mathrm{df}$ & $\mathrm{p}$ \\
\hline ROMs & 0.824 & 54 & 0.413 \\
OXY & 0.107 & 54 & 0.915 \\
GPx & $\mathbf{2 . 5 8 3}$ & $\mathbf{5 4}$ & $\mathbf{0 . 0 1 4}$ \\
SOD & $\mathbf{- 2 . 7 4 1}$ & $\mathbf{5 4}$ & $\mathbf{0 . 0 0 8}$ \\
GPx/SOD & $\mathbf{3 . 3 5 7}$ & $\mathbf{5 4}$ & $\mathbf{0 . 0 0 1}$ \\
Lysozyme & -1.764 & 52 & 0.084 \\
IgG & 0.226 & 53 & 0.822 \\
Haptoglobin & -1.470 & 35 & 0.150 \\
BKA & -1.075 & 22 & 0.294 \\
Body mass & $\mathbf{3 . 8 6 4}$ & $\mathbf{5 4}$ & $\mathbf{0 . 0 0 0 3}$ \\
\hline
\end{tabular}




\title{
Supplementary Material
}

\section{Impacts of land use on an insectivorous tropical bat: the importance of mercury, physio-immunology and trophic position}

\author{
David Costantinia,b,c*, Gábor Á. Czirják ${ }^{\mathrm{d}}$, Paco Bustamante ${ }^{\mathrm{e}}$, \\ Sara Bumrungsri ${ }^{\mathrm{f}}$, Christian C. Voigt ${ }^{\mathrm{c}, \mathrm{g}}$
}

a UMR 7221 CNRS/MNHN, Muséum National d'Histoire Naturelle, Sorbonne Universités, 7 rue Cuvier, Paris 75005, France

b Department of Biology, University of Antwerp, Universiteitsplein 1, Antwerp 2610, Belgium

c Department of Evolutionary Ecology, Leibniz Institute for Zoo and Wildlife Research, Alfred-Kowalke-Straße 17, 10315 Berlin, Germany

${ }^{\mathrm{d}}$ Department of Wildlife Diseases, Leibniz Institute for Zoo and Wildlife Research, AlfredKowalke-Straße 17, 10315 Berlin, Germany

e Littoral Environnement et Sociétés, UMR 7266 CNRS-Université La Rochelle, 2 rue Olympe de Gouges, 17000 La Rochelle, France

${ }^{\mathrm{f}}$ Department of Biology, Faculty of Science, Prince of Songkla University, Hat Yai, Songkhla, Thailand

g Institute of Biology, Freie Universität Berlin, Takustr. 6, Berlin 14195, Germany 
* Corresponding author. Email address: david.costantini@mnhn.fr

\section{Study species}

The wrinkle-lipped free-tailed bat is a cave roosting species that is widespread throughout much of South-East Asia (Csorba et al., 2014). It occurs in large colonies that may count up to 3 million individuals (Leelapaibul et al., 2005). Populations generally forage close to roost sites (within a radius of $25 \mathrm{~km}$ ), and have been recorded hunting above both forested areas and rice fields (Leelaipul et al., 2005; Ruadreo et al., 2019). This species is currently listed as Least Concern by IUCN (Csorba et al., 2014). The population is, however, declining because the habitat is being deforested for timber, firewood and conversion to agricultural use, disturbance in caves (guano mining, hunting), and eradication of colonies (Csorba et al., 2014). It is unknown whether contaminants or diseases play a role in driving these population declines, yet it is assumed that contaminants, such as pesticide residues or mercury, might be involved (Voigt et al., 2018). Wrinkle-lipped free-tailed bats are expected to consume 20,000 MT of insects per year of which many are pest insects highly detrimental for rice production (Leelapaibul et al., 2005). Declines of wrinkle-lipped free-tailed bat populations are suggested to lead to drastic decreases in crop production and consequently to large economic losses (Wanger et al., 2014).

\section{Immunological markers}

Lysozyme, also known as muramidase or $\mathrm{N}$-acetylmuramide glycanhydrolase, is an antibacterial enzyme which hydrolyses the $\beta$-(1,4)-glycosidic bond between $N$ - 
acetylmuramic acid and $\mathrm{N}$-acetylglucosamine residues of bacterial peptidoglycan, causing rapid bacterial lysis. The enzyme is primarily active against Gram-positive bacterial species, but cell lysis has been described both against Gram-negative microorganisms and yeasts. To measure lysozyme concentration, we used the lysoplate assay, which was adapted to low sample volumes (Rowe et al., 2013). Briefly, we prepared 1\% noble agar (Sigma Aldrich) with $\mathrm{PBS}$ at $\mathrm{pH}=6.3$ and we added the required amount of lysozyme-sensitive bacteria Micrococcus lysodeikticus ATCC \#4698 (Sigma Aldrich) to reach a bacterial concentration of $50 \mathrm{mg} / 100 \mathrm{ml}$ in the agar. We poured the agar in Petri dishes on a pre-heated surface $\left(50^{\circ} \mathrm{C}\right)$ and horizontally leveled with a water spirit to avoid quick and uneven cooling of the medium. After solidification, we inoculated $1.5 \mu \mathrm{l}$ of plasma in test holes $(1.7 \mathrm{~mm}$ in diameter). We used standard dilutions of hen egg white lysozyme $(0.5,0.8,1,2,4,8,10,20$, and $40 \mu \mathrm{g} / \mathrm{ml}$; Sigma-Aldrich) to prepare a standard curve in each plate. We incubated the plates at $37^{\circ} \mathrm{C}$ for 20 hours. During the incubation, a zone of clearing developed in the area of the gel surrounding the sample inoculation site as a result of bacterial lysis. The diameters of the cleared zones are proportional to the $\log$ of the lysozyme concentration. We photographed each plate in a photobox (Imaging system; peqlab) with a ruler next to it as a reference scale. We measured the diameter of the cleared zone digitally three times using the software ImageJ (version 1.48, http://imagej.nih.gov/ij/) and we converted the mean value on a semilogarithmic plot into hen egg lysozyme equivalents (HEL equivalents, expressed in $\mu \mathrm{g} / \mathrm{ml}$ ) according to the standard curve (Giraudeau et al., 2010).

We measured the concentration of immunoglobulin $\mathrm{G}(\operatorname{IgG})$, the most common antibody subtype, in plasma with a Protein G ELISA (Schneeberger et al., 2014a; Becker et 
al., 2017, 2018a; Ruoss et al., 2019). Protein G, a streptococcal protein, binds IgG from many wildlife taxa including bats (Schneeberger et al., 2014a). Briefly, high-binding 96-well plates were coated with $100 \mu \mathrm{l}$ diluted plasma samples (1:5000 in $50 \mathrm{mM} \mathrm{NaHCO}$, $\mathrm{pH}$ 9.5) in duplicates and incubated for 1 hour at $37^{\circ} \mathrm{C}$. After incubation, plates were washed in Trisbuffered saline/Tween-20 (TBS-T), blocked with 1\% gelatine (Merck) solution and incubated for $30 \mathrm{~min}$ at $37^{\circ} \mathrm{C}$. After washing, $100 \mu \mathrm{l}$ of Protein G-horseradish peroxidase conjugate solution (Invitrogen, 1:12,000 in TBS-T, pH 7.4) was added to each well. The wells were washed after 30 min incubation at room temperature and submerged with $100 \mu \mathrm{l}$ TMB [10\% 3,3', 5,5'-tetramethylbenzidine (SouthernBiotech) in DMSO (Sigma-Aldrich) diluted 1:100 in phosphate-citric buffer pH 5.0 and mixed with $30 \% \mathrm{H}_{2} \mathrm{O}_{2}$ (Hedinger)]. The reaction was stopped after 3 minutes with $1 \mathrm{M}$ sulphuric acid and the absorbance was read immediately at $450 \mathrm{~nm}$ (Biotek; $\mu$ Quant Microplate Spectrophotometer). Antibody concentration is directly proportional to the absorption, thus statistical analysis was conducted on the mean optical density (OD) of the duplicates (Schneeberger et al., 2014a; Ruoss et al., 2019).

Haptoglobin is an acute phase protein that usually occurs at low concentrations, but its production and secretion is increased in response to acute infections and trauma. To measure the concentration of haptoglobin, the standard procedure of the commercial kit "PHASE"TM Haptoglobin Assay (Tridelta, Ireland) was followed. After diluting the plasma samples (1:2) with PBS, haemoglobin was added. Haptoglobin binds to haemoglobin and maintains its peroxidase activity at a low $\mathrm{pH}$. The measured peroxidase activity of haemoglobin is directly proportional to the amount of haptoglobin in the sample. 
Haptoglobin concentrations were calculated according to the standard curve on each plate and were expressed as $\mathrm{mg} / \mathrm{ml}$.

The BKA of plasma is an integrative functional measurement of the humoral part of the constitutive innate immunity. We performed the assay with Escherichia coli (ATCC 8739) following the method described by French and Neumann-Lee (2012) and adapted to bats (Becker et al., 2017, 2018a; Ruoss et al., 2019). The killing activity against this bacterial strain is mediated mainly through complement proteins (Pap et al., 2010; Becker et al., 2019). We diluted the plasma samples 1:8 in sterile phosphate buffered saline (PBS) and challenged them with a $10^{5} / \mathrm{ml}$ bacterial solution. We incubated the plasma-bacterial mixture for 30 minutes at $37^{\circ} \mathrm{C}$, after which we added tryptic soy broth and we measured the background optical density at $340 \mathrm{~nm}$ (Biotek; $\mu$ Quant Microplate Spectrophotometer). All samples were run in duplicate and all plates contained both positive (without plasma) and negative controls (without bacteria). After an incubation of 12 hours at $37^{\circ} \mathrm{C}$, we measured again the optical density and we calculated the BKA value as one minus mean $\mathrm{OD}_{\text {sample }}$, divided by $\mathrm{OD}$ positive control (OD = optical density; Becker et al., 2018a).

\section{Oxidative status markers}

We measured the reactive oxygen metabolites (primary products of oxidative damage) in plasma using the d-ROMs test (Diacron International, Grosseto, Italy). We pipetted plasma samples, reference standards ( 0.225 to $1.8 \mathrm{mM} \mathrm{H}_{2} \mathrm{O}_{2}$ equivalents), blanks and quality controls (4 $\mu 1) \backslash$ in duplicate in 96-well plates. Using a multichannel pipette, we added to each well $200 \mu \mathrm{l}$ of a solution containing acetic acid/sodium acetate buffer $(0.01 \mathrm{M}, \mathrm{pH} 4.8)$ and the 
chromogen N,N-diethyl-p-phenylenediamine (ratio 100:1). The reactive oxygen metabolites that occur in the plasma react with the chromogen generating a pink colour, whose intensity is proportional to the concentration. After an incubation at $37^{\circ} \mathrm{C}$ for 75 minutes, we measured the optical density at $505 \mathrm{~nm}$. We expressed the values as $\mathrm{mM}$ of $\mathrm{H}_{2} \mathrm{O}_{2}$ equivalents. Good parallelism between successive dilutions of plasma samples and the standard curve of the assay was obtained $\left(\mathrm{R}^{2}=0.99\right)$.

We measured the plasma non-enzymatic antioxidant capacity using the OXYadsorbent test (Diacron International, Grosseto, Italy). This assay quantifies the in vitro reaction between the non-enzymatic antioxidants (e.g., protein thiols, vitamins $\mathrm{C}$ and $\mathrm{E}$ ) and the hypochlorous acid ( $\mathrm{HOCl}$; pro-oxidant generated endogenously by vertebrates). All plasma samples, reference standard $(300 \mathrm{mM})$ and quality controls were initially diluted 1:100 with distilled water. Then, we pipetted $5 \mu \mathrm{l}$ of each one in duplicate in 96-well plates and we added straightaway $200 \mu \mathrm{l}$ of $\mathrm{HOCl}$ using a multichannel pipette. After an incubation at $37^{\circ} \mathrm{C}$ for 10 minutes, we added $2 \mu \mathrm{l}$ of N,N-diethyl-p-phenylenediamine to each well using a multichannel pipette and mixed. The N,N-diethyl-p-phenylenediamine reacts with the $\mathrm{HOCl}$ that did not react with the plasma antioxidants, generating a pink colour. We measured the optical density at $505 \mathrm{~nm}$ and we expressed the OXY values as $\mathrm{mM}$ of $\mathrm{HOCl}$ neutralized.

We measured the activity of the antioxidant enzyme glutathione peroxidase (GPx) in erythrocytes using the Ransel test (Randox Laboratories, Crumlin, UK). First, we made haemolysates by diluting an amount of erythrocytes into distilled water. We added $2 \mu \mathrm{l}$ of haemolysate to $200 \mu \mathrm{l}$ of a reagent ( $4 \mathrm{mM}$ glutathione; $0.34 \mathrm{mM}$ NADPH; glutathione reductase) diluted in buffer (phosphate buffer $0.05 \mathrm{M}$ and $\mathrm{pH} 7.2 ; 4.3 \mathrm{mM}$ of EDTA). Then, 
we added $8 \mu$ l of cumene hydroperoxide (substrate of the enzyme) to each well and we measured the optical density in kinetics after 60, 120 and 180 seconds at $340 \mathrm{~nm}$. The change in optical density per minute was taken below 0.1 in order to be in the linear range of the correlation between activity of GPx and optical density. We normalized the activity of GPx by the concentration of proteins in the haemolysate and we expressed it as units per mg of proteins. We used the Bradford test with albumin as reference standard (Sigma-Aldrich) to measure the protein concentration.

We measured the activity of the antioxidant enzyme superoxide dismutase (SOD) in erythrocytes using the Ransod test (Randox Laboratories, Crumlin, UK). We added $6 \mu$ of the haemolysate used for the GPx to $200 \mu \mathrm{l}$ of a buffer (CAPS $40 \mathrm{mM}$ and pH 10.2; 0.94 mM EDTA) containing the substrate of the enzyme (0.05 mM xanthine; $0.025 \mathrm{mM}$ I.N.T.). Then, using a multichannel pipette, we added $30 \mu 1$ of xanthine oxidase to each well and we measured the optical density in kinetics after 30 seconds and 210 seconds at $505 \mathrm{~nm}$. The reaction between xanthin and xanthin oxidase generates the superoxide which reacts with I.N.T. generating a red colouration. The SOD present in the sample inhibits the reaction between the superoxide and I.N.T. We normalized the activity of SOD by the concentration of proteins in the haemolysate as for the GPx and we expressed it as units per mg of proteins. We calculated the activity of SOD using a reference standard with a known activity of the SOD enzyme.

\section{References}


Becker, D.J., Chumchal, M.M., Bentz, A.B., Platt, S.G., Czirják, G.Á., Rainwater, T.R., Altizer, S., Streicker, D.G., 2017. Predictors and immunological correlates of sublethal mercury exposure in vampire bats. R. Soc. Open Sci. 4, 170073.

Becker, D.J., Czirják, G.Á., Volokhov, D.V., Bentz, A.B., Carrera, J.E., Camus, M.S., Navara, K.J., Chizhikov, V.E., Simmons, N.B., Fenton, M.B., Recuenco, S.E., Gilbert, A.T., Altizer, S., Streicker, D.G., 2018a. Livestock abundance predicts vampire bat demography, immune profiles, and bacterial infection risk. Phil. Trans. R. Soc. B 373, 20170089.

Becker, D.J., Czirják, G.Á., Rynda-Apple, A., Plowright, R.K., 2019. Handling stress and $\underline{\text { sample storage are associated with weaker complement-mediated bactericidal ability in }}$ birds but not bats. Physiol. Biochem. Zool. 92, 37-48.

Csorba, G., Bumrungsri, S., Francis, C., Bates, P., Ong, P., Gumal, M., Kingston, T., Heaney, L., Balete, D., Molur, S., Srinivasulu, C., 2014. Chaerephon plicatus. The IUCN Red List of Threatened Species, e.T4316A67361960

French, S.S., Neuman-Lee, L.A., 2012. Improved ex vivo method for microbiocidal activity across vertebrate species. Biol Open. 1, 482-487.

Giraudeau, M., Czirják, G.Á., Duval, C., Bretagnolle, V., Eraud, C., McGraw, K.J., Heeb, P., 2010. Effect of restricted preen-gland access on maternal self maintenance and reproductive investment in mallards. PLOS ONE 5, e13555.

Leelapaibul, W., Bumrungsri, S., Pattanawiboon, A., 2005. Diet of wrinkle-lipped free-tailed bat (Tadarida plicata Buchannan, 1800) in central Thailand: insectivorous bats potentially act as biological pest control agents. Acta Chiropterol. 7, 111-119.

Pap, P.L., Czirják, G.Á., Vágási, C.I., Barta, Z., Hasselquist, D., 2010. Sexual dimorphism in immune function changes during the annual cycle in house sparrows. Naturwissenschaften 97, 891-901.

Rowe, M., Czirják, G.Á., Lifjeld, J.T., Giraudeau, M., 2013. Lysozyme-associated bactericidal activity in the ejaculate of a wild passerine. Biol. J. Linnean Soc. 109, 92100. 
Ruadreo, N., Voigt, C.C., Bumrungsri, S., 2019. Large dietary niche overlap of sympatric open-space foraging bats revealed by carbon and nitrogen stable isotopes. Acta Chiropterol. 20: 329-341.

Ruoss, S., Becker, N.I., Otto, M.S., Czirják, G.Á., Encarnação, J.A., 2019. Effect of sex and reproductive status on the immunity of the temperate bat Myotis daubentonii. Mammal Biol. 94: 120-126.

Schneeberger, K., Courtiol, A., Czirják, G.Á., Voigt, C.C., 2014a. Immune profile predicts survival in a small, long-lived bat, the greater sac-winged bat (Saccopteryx bilineata). PLoS ONE 9, e108268.

Voigt, C.C., Currie, S.E., Fritze, M., Roeleke, M., Lindecke, O., 2018. Conservation strategies for bats flying at high altitudes. BioScience 68, 427-435.

Wanger, T.C., Darras, K., Bumrungsri, S., Tscharntke, T., Klein, A.-M., 2014. Bat pest control contributes to food security in Thailand. Biol. Conserv. 171, 220-223. 
Table S1. Outcomes of general linear models. Significant effects are shown in bold type. * indicates that the model was re-run after exclusion of statistical outliers.

\begin{tabular}{|c|c|c|c|}
\hline Variable & Environment & Sex & Environment $\times$ Sex \\
\hline$\delta^{15} \mathrm{~N}$ & $\mathrm{~F} 1,100=35.93, \mathrm{p}<0.001$ & $F 1,100=9.60, p=0.003$ & $\mathrm{~F} 1,100=10.66, p=0.002$ \\
\hline$\delta^{13} \mathrm{C}$ & $\mathrm{F} 1,100=50.71, \mathrm{p}<0.001$ & $F 1,100=6.93, p=0.010$ & $F 1,100=12.18, p=0.001$ \\
\hline Mercury & $\mathrm{F} 1,100=17.81, \mathrm{p}<0.001$ & $\mathrm{~F} 1,100=2.34, \mathrm{p}=0.130$ & $\mathrm{~F} 1,100=3.38, \mathrm{p}=0.069$ \\
\hline ROMs & $\mathrm{F} 1,100=1.14, \mathrm{p}=0.289$ & $\mathrm{~F} 1,100=1.29, \mathrm{p}=0.258$ & $\mathrm{~F} 1,100=0.98, \mathrm{p}=0.984$ \\
\hline OXY & $\mathrm{F} 1,100=0.85, \mathrm{p}=0.848$ & $\mathrm{~F} 1,100=21.70, \mathrm{p}<0.001$ & $\mathrm{~F} 1,100=0.53, \mathrm{p}=0.47$ \\
\hline GPx & $\mathrm{F} 1,100=3.99, p=0.048$ & $\mathrm{~F} 1,100=0.24, \mathrm{p}=0.627$ & $\mathrm{~F} 1,100=0.04, \mathrm{p}=0.846$ \\
\hline SOD & $\mathrm{F} 1,100=4.23, p=0.042$ & $\mathrm{~F} 1,100=0.24, \mathrm{p}=0.625$ & $\mathrm{~F} 1,100=2.38, \mathrm{p}=0.126$ \\
\hline GPx/SOD & $F 1,100=6.75, p=0.011$ & $\mathrm{~F} 1,100=0.51, \mathrm{p}=0.476$ & $\mathrm{~F} 1,100=0.41, \mathrm{p}=0.522$ \\
\hline Lysozyme & $\mathrm{F} 1,97<0.01, \mathrm{p}=0.986$ & $\mathrm{~F} 1,97=0.74, \mathrm{p}=0.391$ & $\mathrm{~F} 1,97=0.03, \mathrm{p}=0.867$ \\
\hline IgG & $\mathrm{F} 1,99=0.48, \mathrm{p}=0.489$ & $\mathrm{~F} 1,99=1.24, \mathrm{p}=0.268$ & $\mathrm{~F} 1,99=2.25, \mathrm{p}=0.136$ \\
\hline Haptoglobin & $\mathrm{F} 1,67=1.29, \mathrm{p}=0.259$ & $F 1,67=5.65, p=0.020$ & $\mathrm{~F} 1,67=0.24, \mathrm{p}=0.622$ \\
\hline Haptoglobin * & $\mathrm{F} 1,63=1.25, \mathrm{p}=0.267$ & $\mathrm{~F} 1,63=2.37, \mathrm{p}=0.128$ & $\mathrm{~F} 1,63=0.10, \mathrm{p}=0.754$ \\
\hline BKA & $\mathrm{F} 1,37=0.17, \mathrm{p}=0.682$ & $\mathrm{~F} 1,37=0.71, \mathrm{p}=0.403$ & $\mathrm{~F} 1,37=0.03, \mathrm{p}=0.864$ \\
\hline Body mass & $\mathrm{F} 1,100=5.33, p=0.023$ & $\mathrm{~F} 1,100<0.01, \mathrm{p}=0.996$ & $\mathrm{~F} 1,100=2.61, \mathrm{p}=0.116$ \\
\hline
\end{tabular}


Table S2. Pearson correlations between mercury and all the variables measured in bats. Significant correlations are shown in bold type.

\begin{tabular}{|c|c|c|}
\hline & Before outlier removal & After outlier removal \\
\hline$\delta^{15} \mathrm{~N}$ & $\mathrm{r}=-0.11, \mathrm{p}=0.249, \mathrm{n}=104$ & $\mathrm{r}=-0.05, \mathrm{p}=0.588, \mathrm{n}=103$ \\
\hline$\delta^{13} \mathrm{C}$ & $\mathrm{r}=-0.08, \mathrm{p}=0.449, \mathrm{n}=104$ & $\mathrm{r}=-0.001, \mathrm{p}=0.993, \mathrm{n}=103$ \\
\hline ROMs & $\mathrm{r}=-0.07, \mathrm{p}=0.254, \mathrm{n}=104$ & $\mathrm{r}=-0.06, \mathrm{p}=0.284, \mathrm{n}=103$ \\
\hline OXY & $r=-0.23, p=0.01, n=104$ & $r=-0.21, p=0.015, n=103$ \\
\hline GPx & $\mathrm{r}=0.04, \mathrm{p}=0.352, \mathrm{n}=104$ & $\mathrm{r}=0.06, \mathrm{p}=0.289, \mathrm{n}=103$ \\
\hline SOD & $r=-0.17, p=0.042, n=104$ & $\mathrm{r}=-0.07, \mathrm{p}=0.236, \mathrm{n}=103$ \\
\hline GPx/SOD & $\mathrm{r}=0.10, \mathrm{p}=0.157, \mathrm{n}=104$ & $\mathrm{r}=0.08, \mathrm{p}=0.209, \mathrm{n}=103$ \\
\hline Lysozyme & $\mathrm{r}=0.003, \mathrm{p}=0.488, \mathrm{n}=101$ & $\mathrm{r}=0.21, \mathrm{p}=0.043, \mathrm{n}=98$ \\
\hline $\mathrm{IgG}$ & $r=0.17, p=0.044, n=103$ & $r=0.23, p=0.009, n=102$ \\
\hline Haptoglobin & $\mathrm{r}=-0.16, \mathrm{p}=0.089, \mathrm{n}=71$ & $\mathrm{r}=-0.21, \mathrm{p}=0.090, \mathrm{n}=66$ \\
\hline BKA & $\mathrm{r}=-0.05, \mathrm{p}=0.385, \mathrm{n}=41$ & $\mathrm{r}=-0.02, \mathrm{p}=0.444, \mathrm{n}=40$ \\
\hline Body mass & $\mathrm{r}=0.40, \mathrm{p}<0.001, \mathrm{n}=104$ & $r=0.44, p<0.001, n=103$ \\
\hline
\end{tabular}

